\title{
The endocannabinoid system: an overview
}

\author{
Natalia Battista ${ }^{1,2 *}$, Monia Di Tommaso ${ }^{1}$, Monica Bari ${ }^{3}$ and Mauro Maccarrone ${ }^{1,2}$ \\ ' Department of Biomedical Sciences, University of Teramo, Teramo, Italy \\ 2 European Center for Brain Research (CERC)/Santa Lucia Foundation, Rome, Italy \\ ${ }^{3}$ Department of Experimental Medicine and Biochemical Sciences, University of Rome "Tor Vergata," Rome, Italy
}

\author{
Edited by: \\ Patrizia Campolongo, Università \\ degli Studi di Roma La Sapienza, \\ Italy \\ Reviewed by: \\ Tiziana Bisogno, National Research \\ Council, Italy \\ Bruno M. Fonseca, Instituto de \\ Biologia Molecular e Celular da \\ Universidade do Porto, Portugal \\ *Correspondence: \\ Natalia Battista, Department of \\ Biomedical Sciences, University of \\ Teramo, Piazza A. Moro, 45, Teramo \\ 64100, Italy. \\ e-mail:nbattista@unite.it
}

Upon the identification of anandamide (AEA) in the porcine brain, numerous studies contributed to the current state of knowledge regarding all elements that form the "endocannabinoid system (ECS)." How this complex system of receptors, ligands, and enzymes is integrated in helping to regulate fundamental processes at level of central nervous and peripheral systems and how its regulation and dysregulation might counteract disturbances of such functions, is nowadays still under investigation. However, the most recent advances on the physiological distribution and functional role of ECS allowed the progress of various research tools aimed at the therapeutic exploitation of endocannabinoid (eCB) signaling, as well as the development of novel drugs with pharmacological advantages. Here, we shall briefly overview the metabolic and signal transduction pathways of the main eCBs representatives, AEA, and 2-arachidonoylglycerol (2-AG), and we will discuss the therapeutic potential of new ECS-oriented drugs.

Keywords: anandamide, 2-arachidonoylglycerol, endocannabinoids, metabolic pathways, signal transduction

\section{ENDOCANNABINOID SYSTEM: METABOLISM AND TARGETS OF ENDOCANNABINOIDS}

Starting from 1992, when anandamide (AEA) was identified for the first time in the porcine brain (Devane et al., 1992), numerous studies contributed to the current state of knowledge regarding all elements that form the "endocannabinoid system (ECS)" (Maccarrone et al., 2010). Endocannabinoids (eCBs) are lipid mediators, isolated from brain and peripheral tissues that include amides, esters, and ethers of long chain polyunsaturated fatty acids; they mimic the action of $\Delta^{9}$-tetrahydrocannabinol (THC) in different biological processes. Until now, the most bioactive eCBs are anandamide (arachidonylethanolamide; AEA) and 2-arachidonoylglycerol (2-AG), yet the eCBs family includes also virodhamine, noladin ether, and $\mathrm{N}$-arachidonoyldopamine (NADA), besides homo-linolenylethanolamide (HEA), docosatetraenylethanolamide (DEA), and other cognate compounds such as palmitoylethanolamide (PEA) and oleoylethanolamide (OEA) (Figure 1).

eCBs are released "on demand" from membrane phospholipid precursors and, although AEA synthesis might be due to several metabolic routes (Muccioli, 2010), $\mathrm{N}$-acylphosphatidylethanolamine-specific phospholipase D (NAPE-PLD) is currently considered the major enzyme responsible for AEA production (Okamoto et al., 2009), whereas a specific phospholipase C followed by the activity of the sn-1-diacylglycerol lipase (DAGL) is responsible for 2-AG synthesis (Ueda et al., 2011). The cellular uptake from the extracellular to the intracellular space is ascribed to a purported "endocannabinoid membrane transporter (EMT)" that is likely to take up both AEA and 2-AG. However, while there is wide experimental evidence to support the concept that AEA transport across membranes is protein-mediated, conclusive evidence of its molecular identity is still lacking. Very recently, a partly truncated fatty acid amide hydrolase-1 (FAAH-1) termed FAAH-1 like anandamide transporter (FLAT) has been reported in neural cells (Fu et al., 2011). After re-uptake, the biological activity of eCBs is ended by a FAAH, for AEA (McKinney and Cravatt, 2005), and/or by a specific monoacylglycerol lipase (MAGL), for 2AG (Dinh et al., 2002). Additionally, other enzymes showing "amidase signature," such as FAAH-2 (Wei et al., 2006) and the $\mathrm{N}$-acylethanolamine-hydrolyzing acid amidase (NAAA) (Tsuboi et al., 2005), which belongs to the choloylglycine hydrolase family, might bind with low affinity and hydrolyse AEA to release arachidonic acid and ethanolamine. Also cyclooxygenase-2 (COX-2), different lipoxygenase (LOX) isozymes and cytochrome $\mathrm{P} 450$ are able to accept AEA and 2-AG as a substrate, leading to the biosynthesis of prostaglandin-ethanolamides (Kozak et al., 2002) and -glyceryl esters (Kozak et al., 2001), hydroxy-anandamides, and hydroxyleicosatetraenoyl-glycerols (van der Stelt et al., 2002), respectively. For a comprehensive review on alternative pathways of eCBs see and Rouzer and Marnett (Rouzer and Marnett, 2011). eCBs act principally through cannabinoid receptors, that include type- 1 and type- $2\left(\mathrm{CB}_{1}\right.$ and $\left.\mathrm{CB}_{2}\right)$ receptors; more recently, it has been highlighted the ability of some $\mathrm{CB}$ and non-CB ligands to bind also to GPR55 (Glucksmann and Weich, 1999; Wise and Brown, 2001; Drmota et al., 2004; Pertwee, 2007; Ryberg et al., 2007; Lauckner et al., 2008), thus suggesting that the latter protein might act as a novel "type-3 $\left(\mathrm{CB}_{3}\right)$ " cannabinoid receptor (Moriconi et al., 2010). CB receptors are members of the large family of heptahelical G protein coupled receptors (GPCRs), activate Gi/o proteins (Pertwee et al., 2010). Anatomical studies have revealed that these receptors display a highly divergent pattern of distribution throughout the organism: $\mathrm{CB}_{1}$ mainly present in the central nervous system (Herkenham et al., 1991) and, on the other hand, $\mathrm{CB}_{2}$ mainly distributed in peripheral and immune cells (Munro et al., 1993). This topographical dichotomy has been 


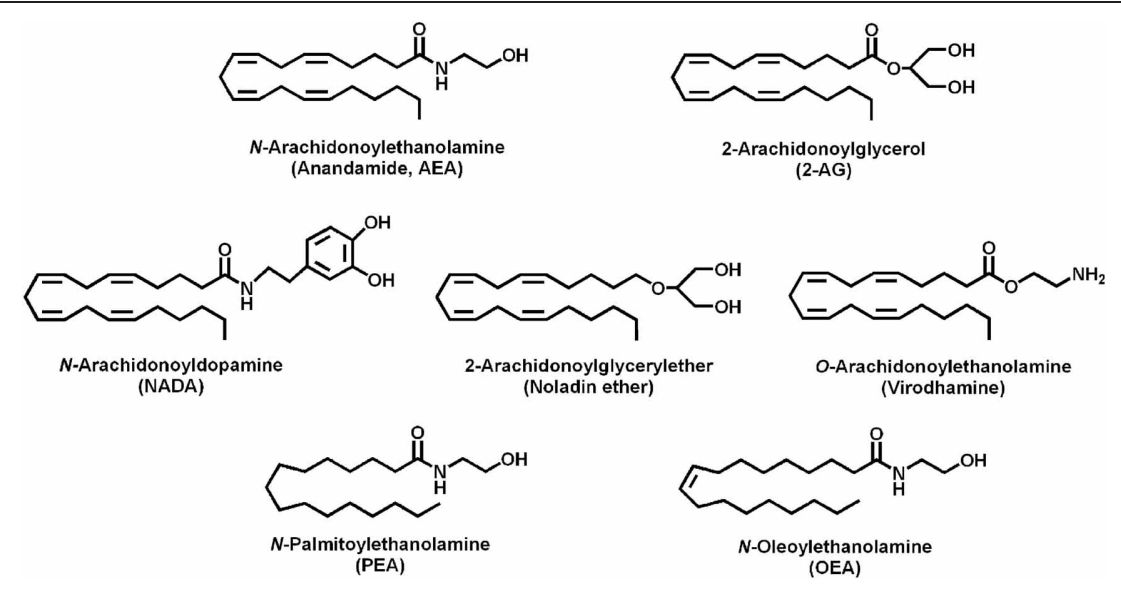

FIGURE 1 | Chemical structures of biologically active eCBs and of the eCB-like compounds.

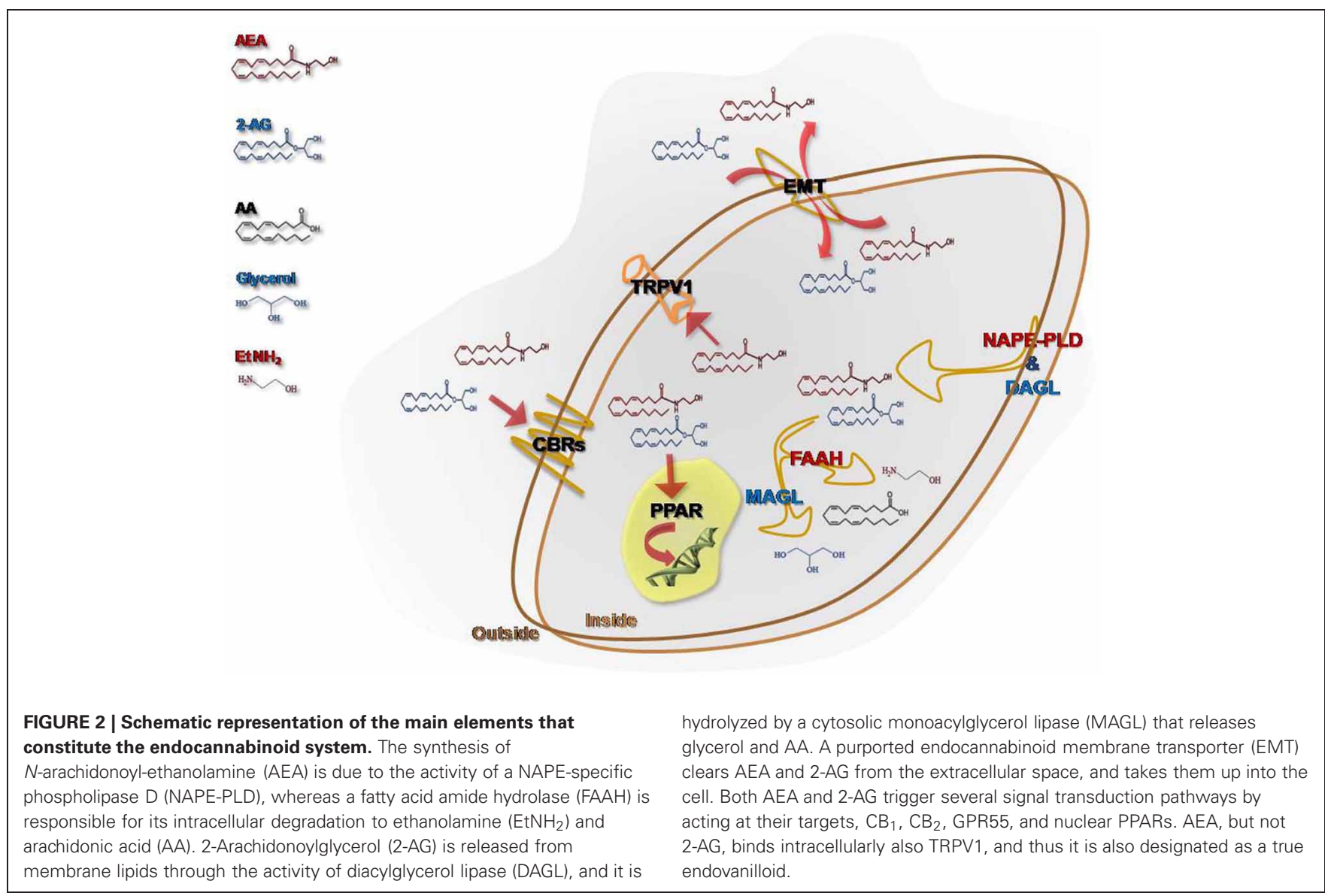

revised by a number of studies documenting the presence of $\mathrm{CB}_{1}$ in several non-neuronal cells and tissues (Gong et al., 2006), and of $\mathrm{CB}_{2}$ in the brain stem (van Sickle et al., 2005) and in neuronal cells upon exogenous insults (Viscomi et al., 2009). In addition, the non-selective cationic channel type-1 vanilloid receptor (transient receptor potential vanilloid 1, TRPV1), usually activated by capsaicin and by noxious stimuli-like heat and protons (Di Marzo and De Petrocellis, 2010), is an alternative target for AEA, but not for 2-AG. More recently, also nuclear receptors like the peroxisome proliferator-activated receptors (PPARs) have been added to the list of eCBs targets, activated under physiological and pathological conditions (Pistis and Melis, 2010). A schematic representation of eCBs, their receptors, biosynthetic and catabolic enzymes, as well as putative transporter, is depicted in Figure 2. 


\section{ECBS AND THEIR SIGNAL TRANSDUCTION PATHWAYS}

The signal transduction pathways coupled to CB, TRPV1, and PPAR receptors are summarized in Table 1. Among the effects elicited by $\mathrm{eCBs}$ by binding to $\mathrm{CB}$ receptors, we should recall $\mathrm{Ca}^{2+}$ channels inhibition (including N-, P/Q-, and L-type channels), inhibition of adenylyl cyclase and subsequent decrease of cAMP-dependent protein kinase, which leads to decreased phosphorylation of the $\mathrm{K}^{+}$channels, regulation of ionic currents, activation of focal adhesion kinase, stimulation of mitogen-activated protein kinase (MAPK) cascades (Pertwee, 2006), and specifically ERK, p38 MAPK cascades (Derkinderen et al., 2001; Gertsch et al., 2004), and the stimulation of additional intracellular pathways including the phosphatidylinositol 3-kinase (PI3K)/Akt pathway through $\mathrm{CB}_{2}$ (Molina-Holgado et al., 2002).

Unlike $\mathrm{CB}_{2}, \mathrm{CB}_{1}$ receptors are associated to special membrane microdomains, called "lipid rafts" (LR) that modulate $\mathrm{CB}_{1}$-dependent signaling pathways. The functional relationship between $\mathrm{CB}_{1}$ and LR is affected by cholesterol content; in particular, membrane cholesterol enrichment in both primary and immortalized cell lines reduces the binding to $\mathrm{CB}_{1}$ and subsequent G-protein dependent signaling through adenylyl cyclase and MAPK (Bari et al., 2005). Moreover, the disruption of LRs by cholesterol depletion modifies AEA-induced endocytosis of $\mathrm{CB}_{1}$, which apparently loses the capacity to be directed toward the lysosomal compartment. Therefore, LRs, besides representing a favorable platform to regulate $\mathrm{CB}_{1}$ signaling, might also represent a cellular device for its intracellular trafficking (Sarnataro et al., 2005; Dainese et al., 2007). The general model to explain the neuromodulatory actions of AEA involves the release of eCBs from a postsynaptic neuron upon stimulation, then the back diffusion to presynaptic terminals, where AEA activates $\mathrm{CB}_{1}$ receptors, thus modulating neuronal membrane permeability to $\mathrm{Ca}^{2+} \mathrm{e} \mathrm{K}^{+}$ions and the activity of adenylyl cyclase. The final outcome is a modified action of neurotransmitters (Di Marzo and De Petrocellis, 2010).

Table 1 | Signal transduction pathways triggered by eCBs at different target receptors.

\begin{tabular}{|c|c|}
\hline Receptor & Effect \\
\hline $\mathrm{CB}_{1}$ and $\mathrm{CB}_{2}$ & $\begin{array}{l}\downarrow \text { Adenylyl cyclase } \\
\uparrow \text { Focal adhesion kinase (FAK) and mitogen-activated } \\
\quad \text { protein kinase (MAPK) } \\
\uparrow \text { ERK, p38 through } \mathrm{CB}_{1} \text {, and PI3K/Akt through } \mathrm{CB}_{2} \\
\uparrow \mathrm{K}^{+} \text {channels } \\
\downarrow \mathrm{Ca}^{2+} \text { channels }\end{array}$ \\
\hline GPR55 & $\begin{array}{l}\uparrow \text { Intracellular }\left[\mathrm{Ca}^{2+}\right] \\
\uparrow \text { RhoA, Rac, and Cdc42 } \\
\uparrow \text { ERK phosphorylation }\end{array}$ \\
\hline TRPV1 & $\begin{array}{l}\uparrow \text { Intracellular }\left[\mathrm{Ca}^{2+}\right] \\
\uparrow \text { Caspases } \\
\uparrow \text { Cytochrome c release } \\
\uparrow \text { Mitochondrial uncoupling } \\
\uparrow \text { Pro-apoptotic kinases }\end{array}$ \\
\hline PPARs & $\begin{array}{l}\uparrow \text { ROS } \\
\uparrow \text { Tyrosine kinases } \\
\uparrow \text { Adiponectin and lipoprotein lipase }\end{array}$ \\
\hline
\end{tabular}

The activation of GPR55, the purported " $\mathrm{CB}_{3}$ " cannabinoid receptor, has been linked to (1) intracellular $\mathrm{Ca}^{2+}$ increase (Lauckner et al., 2008); (2) activation of the small GTPase proteins RhoA, Rac, and Cdc42 (Ryberg et al., 2007; Henstridge et al., 2009), and (3) ERK phosphorylation (Oka et al., 2007, 2009). Additionally, by triggering PPARs, eCBs exert a variety of long-term effects via genomic mechanisms and rapid nongenomic actions, which are opposite to those evoked by activation of "classical" surface cannabinoid receptors (Pistis and Melis, 2010). As a consequence, PPARs activation affects several physiological and pathological processes, such as lipid metabolism, energy balance, and feeding behavior, neuroprotection, epilepsy, circadian rhythms, inflammation, addiction, and cognitive functions (Pistis and Melis, 2010). However, AEA can also act as a modulator of other signaling pathways and, in fact, it has been observed that muscarinic and glutamate receptors have allosteric sites for AEA binding (Lanzafame et al., 2004). In this context, it should be underlined that there are several findings showing that eCBs modulate the signaling of several neuropeptides and hormones (Manzanares et al., 1999; Beinfeld and Connolly, 2001; Ghozland et al., 2002). This highly complex network of interactions is reflected in the multifaceted modulatory effects of eCBs on the regulation of brain and behavioral functions (López-Moreno et al., 2008).

\section{PHYSIOLOGICAL ACTIONS OF ECS AND THERAPEUTIC PERSPECTIVES}

The presence of ECS in vertebrates, mammals, and humans implies a role in several physiological processes, including appetite, cancer, cardiovascular diseases, fertility, immune functions, memory, neuroprotection, and pain modulation (Ligresti et al., 2009; Maccarrone et al., 2010) (Figure 3).

In the last 10 years, it has become clear that a dysregulation of ECS is connected to pathological conditions, and thus its modulation through inhibition of metabolic pathways and/or agonism or antagonism of its receptors has an enormous potential for research and intervention in multiple areas of human health.

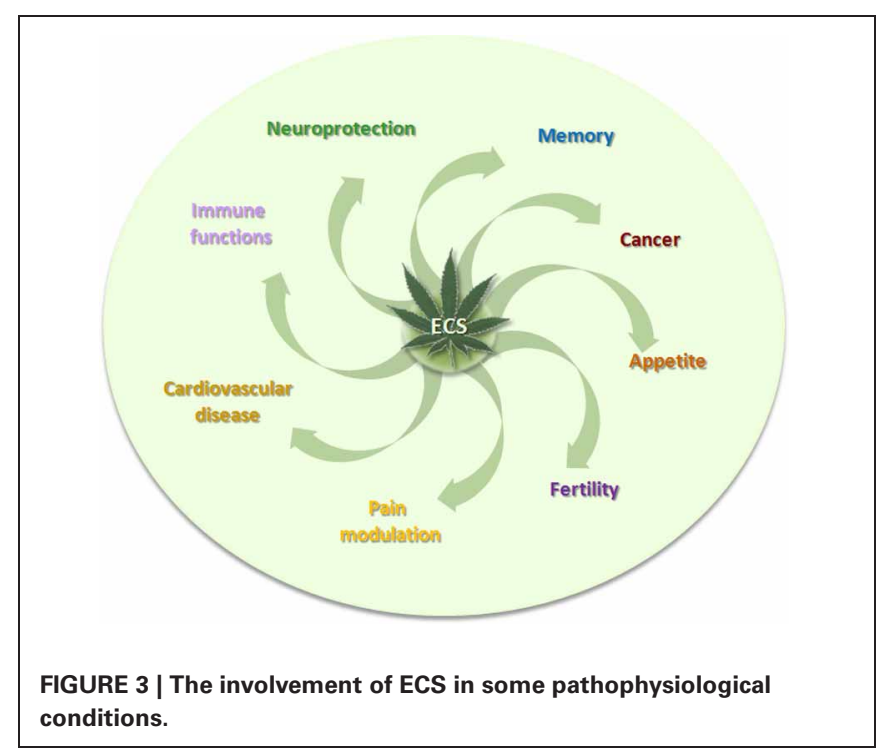


Therefore, based on the therapeutic potential of THC, known since centuries as medicine for its palliative effects in several pathologies, plant-derived cannabinoids, synthetic cannabinoids, and eCBs have been tested as novel therapeutics in a wide range of clinical trials.

The neuroprotective effect of eCBs might be mediated by either $\mathrm{CB}_{1}$ - or $\mathrm{CB}_{2}$-dependent mechanisms. Research studies using $c b_{1}^{-/-}$knock-out mice showed an increased mortality rate and an increased infarct area in cerebral ischemia models (Parmentier-Batteur et al., 2002). It has been reported that the administration of the $\mathrm{CB}_{1}$ synthetic agonist WIN 55.212-2 attenuated the neurological damage and reduced infarct size in artery occlusion induced in rats (Nagayama et al., 1999), and additionally it reduced the glial damage after hypoxic-ischemic brain injury in preterm lambs (Alonso-Alconada et al., 2010). The presence of $\mathrm{CB}_{2}$-positive cells in the brain during injury and in inflammatory neurodegenerative disorders might provide a novel strategy for cannabinoid-mediated intervention against strokeinduced neurodegeneration, without the unwanted psychoactive effects of $\mathrm{CB}_{1}$ receptor stimulation (Cunha et al., 2011). O-3853 and O-1966, two selective $\mathrm{CB}_{2}$ agonists, administrated $1 \mathrm{~h}$ before transient middle cerebral artery occlusion, significantly decreased the mobilization of white blood cells and their adherence to vascular endothelial cells, reduced the infarct size, and improved motor function after transient focal ischemia (Zhang et al., 2007, 2009).

According to these observations, pain management is preferably handled using $\mathrm{CB}_{2}$ agonists, such as HU-308 and AM-1241, which display significant relief in inflammatory and neuropathic pain models, without exhibiting central nervous system side effects (Hanus et al., 1999; Yao et al., 2006). In this context, new selective $\mathrm{CB}_{2}$ receptor modulators, designed by Glaxo Smith Kline as derivatives of pyrimidinecarboxamide, have been tested as good clinical candidates to treat inflammatory, acute, and chronic pain (Giblin et al., 2007, 2009).

In the past, several reports documented that the selective pharmacologic antagonism of the $\mathrm{CB}_{1}$ receptor improves lipid abnormalities associated with obesity, as well as neurodegenerative diseases and nicotine or alcohol dependence (Centonze et al., 2007; Di Marzo, 2008). Following the good outcome obtained in

Table 2 | Chemical structures and therapeutic potential of some ECS-targeted molecules.

\begin{tabular}{|c|c|c|c|c|}
\hline Chemical structure & Compound & ECS target & Diseases & References \\
\hline & PF-04457845 & FAAH & Pain, Osteoarthritis & Ahn et al., 2011 \\
\hline & URB 597 & & $\begin{array}{l}\text { Anxiety, Cannabis dependence, } \\
\text { Hyperalgesia }\end{array}$ & Bortolato et al., 2007 \\
\hline & SR141716A & $\mathrm{CB}_{1}$ & Eating disorder & Christopoulou and Kiortsis, 2011 \\
\hline
\end{tabular}<smiles>CCN(C)NC(=O)c1nn(-c2ccc(Cl)cc2Cl)c(-c2ccc(Cl)cc2)c1C</smiles>

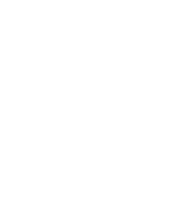

WIN 55.212-2
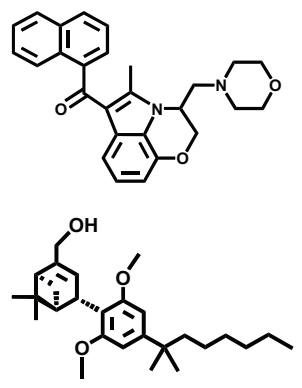

?

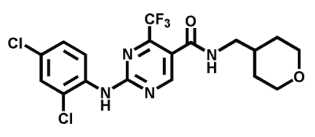

GW842166X
Ischemic stroke, Brain injury

Neuropathic pain

Acute/chronic pain
Nagayama et al., 1999;

Alonso-Alconada et al., 2010

Hanus et al., 1999

Giblin et al., 2009
$\mathrm{CB}_{2}$

GSK554418A
Inflammatory pain

Giblin et al., 2007 
various clinical trials, the best known $\mathrm{CB}_{1}$ blocker SR141617A, also called rimonabant (and commercially known as Acomplia ${ }^{\circledR}$ ) was released on the worldwide market as anti-obesity drug, but only few months later it was withdrawn because of increased rates of depression, anxiety, and suicide among patients who received it (Christopoulou and Kiortsis, 2011). In addition, further concerns were raised considering the possible side effects of this weight loss pill on the reproductive functions and human infertility (Bari et al., 2011).

Alternative strategies to treat pain syndromes, such as neuropathic pain, fibromyalgia, but also spontaneous abortion, headache, psychiatric disorders, and neurodegenerative diseases, are based on the enhacement of the $\mathrm{eCB}$ tone, through the inhibition of eCBs-hydrolyzing enzymes (Lichtman and Chapman, 2001). The most promising FAAH inhibitor seems to be URB597 (also named KDS-4103), which has biochemical and behavioral effects during both sub-acute and chronic treatments. In rodents, once-daily dosing of URB597 for five weeks elicits antidepressant effects in chronically stressed animals, without altering $\mathrm{CB}_{1}$ receptor mRNA levels (Bortolato et al., 2007). Pfizer and Vernalis pharmaceutical companies focused on FAAH as main target to design and develop new molecules (PF-04457845 and V158866, respectively), that are being tested in clinical studies as potential therapies for a range of pain disorders, including osteoarthritis

\section{REFERENCES}

Ahn, K., Smith, S. E., Liimatta, M. B., Beidler, D., Sadagopan, N., Dudley, D. T., Young, T., Wren, P., Zhang, Y., Swaney, S., Van Becelaere, K., Blankman, J. L., Nomura, D. K., Bhattachar, S. N., Stiff, C., Nomanbhoy, T. K., Weerapana, E., Johnson, D. S., and Cravatt, B. F. (2011). Mechanistic and pharmacological characterization of PF04457845: a highly potent and selective fatty acid amide hydrolase inhibitor that reduces inflammatory and noninflammatory pain. J.Pharmacol.Exp. Ther. 338, 114-124.

Alonso-Alconada, D., Alvarez, F. J., Alvarez, A., Mielgo, V. E., Goñide-Cerio, F., Rey-Santano, M. C., Caballero, A., Martinez-Orgado, J., and Hilario, E. (2010). The cannabinoid receptor agonist WIN $55,212-2$ reduces the initial cerebral damage after hypoxic-ischemic injury in fetal lambs. Brain Res. 1362, 150-159.

Bari, M., Battista, N., Fezza, F., Finazzi Agrò, A., and Maccarrone, M. (2005). Lipid rafts control signaling of type-1 cannabinoid receptors in neuronal cells. Implications for anandamide-induced apoptosis. $J$. Biol. Chem. 280, 12212-12220.

Bari, M., Battista, N., Pirazzi, V., and Maccarrone, M. (2011). The manifold actions of endocannabinoids on female and male reproductive events. Front. Biosci. 16, 498-516.
Beinfeld, M. C., and Connolly, K. (2001). Activation of CB1 cannabinoid receptors in rat hippocampal slices inhibits potassium-evoked cholecystokinin release, a possible mechanism contributing to the spatial memory defects produced by cannabinoids. Neurosci. Lett. 301, 69-71.

Bortolato, M., Mangieri, R. A., Fu, J., Kim, J. H., Arguello, O., Duranti, A., Tontini, A., Mor, M., Tarzia, G., and Piomelli, D. (2007). Antidepressantlike activity of the fatty acid amide hydrolase inhibitor URB597 in a rat model of chronic mild stress. Biol. Psychiatry 62, 1103-1110.

Centonze, D., Finazzi Agrò, A., Bernardi, G., and Maccarrone, M. (2007). The endocannabinoid system in targeting inflammatory neurodegenerative diseases. Trends Pharmacol. Sci. 28, 180-187.

Christopoulou, F. D., and Kiortsis, the metabolic effects of rimonabant in randomized controlled trials: potential for other cannabinoid 1 receptor blockers in obesity. $J$. Clin. Pharm. Ther. 36, 10-18.

Clapper, J. R., Mangieri, R. A., and Piomelli, D. (2009). The endocannabinoid system as a target for the treatment of cannabis dependence. Neuropharmacology 56, 235-243.

Cunha, P., Romão, A. M., MascarenhasMelo, F., Teixeira, H. M., and Reis, D. N. (2011). An overview of

(Ahn et al., 2011). It is noteworthy that FAAH inhibitors, because of their own pharmacological properties, are attractive remedial also for cannabis dependence; in fact, they do not appear to evoke tolerance following long-term administration, and they do not display significant abuse liability (Clapper et al., 2009). Table 2 reports some agonists, antagonists, and/or inhibitors of ECS designed for the treatment of several pathological conditions.

\section{CONCLUSION}

Almost 20 years after the identification of AEA, all members of ECS are nowadays considered intriguing targets for the development of selective and specific compounds able to modulate human pathophysiology. A deeper and more detailed understanding of proteins involved in eCBs metabolism and signaltransduction pathways could help to design compounds that might prolong the activity of eCBs in a time- and site-dependent way, excluding undesired psychotropic effects, and to develop transgenic mice, where different ECS elements can be knocked down or knocked in, allowing innovative therapeutic strategies in a vast panorama of pathologies.

\section{ACKNOWLEDGMENTS}

This work was partly supported by Fondazione TERCAS (2009-2012 project to Mauro Maccarrone).

F. (2011). Endocannabinoid system in cardiovascular disorders new pharmacotherapeutic opportunities. J. Pharm. Bioallied. Sci. 3, 350-360.

Dainese, E., Oddi, S., Bari, M., and Maccarrone, M. (2007). Modulation of the endocannabinoid system by lipid rafts. Curr. Med. Chem. 14, 2702-2715.

Derkinderen, P., Ledent, C., Parmentier, M., and Girault, J. A. (2001). Cannabinoids activate p38 mitogen-activated protein kinases through $\mathrm{CB} 1$ receptors in hippocampus. J. Neurochem. 77, 957-960.

Devane, W. A., Hanus, L., Breuer, A., Pertwee, R. G., Stevenson, L. A., Griffin, G., Gibson, D., Mandelbaum, A., Etinger, A., and Mechoulam, R. (1992). Isolation and structure of a brain constituent that binds to the cannabinoid receptor. Science 258, 1946-1949.

Di Marzo, V. (2008). CB(1) receptor antagonism: biological basis for metabolic effects. Drug Discov. Today 13, 1026-1041.

Di Marzo, V., and De Petrocellis, L. (2010). Endocannabinoids as regulators of transient receptor potential (TRP) channels: a further opportunity to develop new endocannabinoid-based therapeutic drugs. Curr. Med. Chem. 17, 1430-1449.
Dinh, T. P., Freund, T. F., and Piomelli, D. (2002). A role for monoglyceride lipase in 2-arachidonoylglycerol inactivation. Chem. Phys. Lipids 121, 149-158.

Drmota, T., Greasley, P., and Groblewski, T. (2004). AstraZeneca. WO04074844.

Fu, J., Bottegoni, G., Sasso, O., Bertorelli, R., Rocchia, W., Masetti, M., Guijarro, A., Lodola, A., Armirotti, A., Garau, G., Bandiera, T., Reggiani, A., Mor, M., Cavalli, A., and Piomelli, D. (2011). A catalytically silent FAAH-1 variant drives anandamide transport in neurons. Nat. Neurosci. 15, 64-69.

Gertsch, J., Schoop, R., Kuenzle, U., and Suter, A. (2004). Echinacea alkylamides modulate TNF-alpha gene expression via cannabinoid receptor $\mathrm{CB} 2$ and multiple signal transduction pathways. FEBS Lett. 577, 563-569.

Ghozland, S., Matthes, H. W., Simonin, F., Filliol, D., Kieffer, B. L., and Maldonado, R. (2002). Motivational effects of cannabinoids are mediated by mu-opioid and kappaopioid receptors. J. Neurosci. 22, 1146-1154.

Giblin, G. M. P., Billinton, A., Briggs, M., Brown, A. J., Chessell, I. P., Clayton, N. M., Eatherton, A. J., Goldsmith, P., Haslam, C., Johnson, M. R., Mitchell, W. L., Naylor, A., Perboni, A., Slingsby, B. P., and Wilson, A. W. (2009). Discovery 
of 1-[4-(3-chlorophenylamino)-1methyl-1H-pyrrolo [3,2-c] pyridin7-yl]- 1-morpholin-4-ylmethanone (GSK554418A), a brain penetrant 5-azaindole CB2 agonist for the treatment of chronic pain. J. Med. Chem. 52, 5785-5788.

Giblin, G. M. P., O'Shaughnessy, C. T., Naylor, A., Mitchell, W. L., Eatherton, A. J., Slingsby, B. P., Rawlings, D. A., Goldsmith, P., Brown, A. J., Haslam, C. P., Clayton, N. M., Wilson, A. W., Chessell, I. P., Wittington, A. R., and Green, R. (2007). Discovery of 2-[(2,4-dichlorophenyl)amino]$\mathrm{N}$-[(tetrahydro-2H-pyran-4-yl)methyl]-4-(trifluoromethyl)-5-pyrimidinecarboxamide, a selective CB2 receptor agonist for the treatment of inflammatory pain. J. Med. Chem. 50, 2597-2600.

Glucksmann, M. A., and Weich, N. (1999). Millennium Pharmaceuticals Inc. WO990023588.

Gong, J. P., Onaivi, E. S., Ishiguro, H., Liu, Q. R., Tagliaferro, P. A., Brusco, A., and Uhl, G. R. (2006). Cannabinoid $\mathrm{CB} 2$ receptors: immunohistochemical localization in rat brain. Brain Res. 1071, 10-23.

Hanus, L., Breuer, A., Tchillibon, S., Shiloah, S., Goldenberg, D., Horowitz, M., Pertwee, R. G., Ross, R. A., Mechoulam, R., and Fride, E. (1999). HU-308: a specific agonist for CB2, a peripheral cannabinoid receptor. Proc. Natl. Acad. Sci. U.S.A. 96, 14228-14233.

Henstridge, C. M., Balenga, N. A., Ford, L. A., Ross, R. A., Waldhoer, M., and Irving, A. J. (2009). The GPR55 ligand Lalphalysophosphatidylinositol promotes RhoA-dependent $\mathrm{Ca} 2+$ signaling and NFAT activation. FASEB J. 23, 183-193.

Herkenham, M., Lynn, A. B., Johnson, M. R., Melvin, L. S., de Costa, B. R., and Rice, K. C. (1991). Characterization and localization of cannabinoid receptors in rat brain: a quantitative in vitro autoradiographic study. J. Neurosci. 11, 563-583.

Kozak, K. R., Crews, B. C., Morrow, J. D., Wang, L. H., Ma, H. Y., Weinander, R., Jakobsson, P. J., and Marnett, L. J. (2002). Metabolism of the endocannabinoids, 2-arachidonoyglkycerol and anandamide, into prostaglandin, tromboxane, and prostacyclin glycerol esters and ethanolamides. J. Biol. Chem. 277, 44877-44885.

Kozak, K. R., Crews, B. C., Ray, J. L., Tai, H. H., Morrow, J. D., and Marnett, L. J. (2001). Metabolism of prostaglandin glycerol esters and prostaglandin ethanolamides in vitro and in vivo. J. Biol. Chem. 276 , 36993-36998.

Lanzafame, A. A., Guida, E., and Christopoulos, A. (2004). Effects of anandamide on the binding and signaling properties of M1 muscarinic acetylcholine receptors. Biochem. Pharmacol. 68, 2207-2219.

Lauckner, J. E., Jensen, J. B., Chen, H. Y., Lu, H. C., Hille, B., and Mackie, K. (2008). GPR55 is a cannabinoid receptor that increases intracellular calcium and inhibits $\mathrm{M}$ current. Proc. Natl. Acad. Sci. U.S.A. 105 2699-2704.

Lichtman, A. H., and Chapman, V. (2001). A FAAH-fetched approach to treat osteoarthritis pain. Pain 152 , 959-960.

Ligresti, A., Petrosino, S., and Di Marzo, V. (2009). From endocannabinoid profiling to "endocannabinoid therapeutics". Curr. Opin. Chem. Biol. 13, 21-31.

López-Moreno, J. A., González-Cuevas, G., Moreno, G., and Navarro, M. (2008). The pharmacology of the endocannabinoid system: functional and structural interactions with other neurotransmitter systems and their repercussions in behavioral addiction. Addict. Biol. 13, 160-187.

Maccarrone, M., Dainese, E., and Oddi, S. (2010). Intracellular trafficking of anandamide: new concepts for signaling. Trends Biochem. Sci. 35, 601-608.

Manzanares, J., Corchero, J., Romero, J., Fernandez-Ruiz, J. J., Ramos, J. A., and Fuentes, J. A. (1999) Pharmacological and biochemical interactions between opioids and cannabinoids. Trends Pharmacol. Sci. 20, 287-294.

McKinney, M. K., and Cravatt, B. F. (2005). Structure and function of fatty acid amide hydrolase. Annu. Rev. Biochem. 74, 411-432.

Molina-Holgado, E., Vela, J. M., Arévalo-Martín, A., Almazán, G., Molina-Holgado, F., Borrell, J., and Guaza, C. (2002). Cannabinoids promote oligodendrocyte progenitor survival: involvement of cannabinoid receptors and phosphatidylinositol-3 kinase/Akt signaling. J. Neurosci. 22, 9742-9753.

Moriconi, A., Cerbara, I., Maccarrone, M., and Topai, A. (2010). GPR55: current knowledge and future perspectives of a purported "Type-3" cannabinoid receptor. Curr. Med. Chem. 17, 1411-1429.

Muccioli, G. G. (2010). Endocannabinoid biosynthesis and inactivation, from simple to complex. Drug Discov. Today 15, 474-483.

Munro, S., Munro, S., Thomas, K. L., and Abu-Shaar, M. (1993). Molecular characterization of a peripheral receptor for cannabinoids. Nature 365, 61-65.

Nagayama, T., Sinor, A. D., Simon, R. P., Chen, J., Graham, S. H., Jin, K., and Greenberg, D. A. (1999). Cannabinoids and neuroprotection in global and focal cerebral ischemia and in neuronal cultures. J. Neurosci. 19, 2987-2995.

Oka, S., Nakajima, K., Yamashita, A., Kishimoto, S., and Sugiura, T. (2007). Identification of GPR55 as a lysophosphatidylinositol receptor. Biochem. Biophys. Res. Commun. 362, 928-934.

Oka, S., Toshida, T., Maruyama, K., Nakajima, K., Yamashita, A., and Sugiura, T. (2009). 2-Arachidonoylsn-glycero-3-phosphoinositol: possible natural ligand for GPR55. J. Biochem. 145, 13-20.

Okamoto, Y., Tsuboi, K., and Ueda, N. (2009). Enzymatic formation of anandamide. Vitam. Horm. 81, $1-24$.

Parmentier-Batteur, S., Jin, K., Mao, X. O., Xie, L., and Greenberg, D. A. (2002). Increased severity of stroke in CB1 cannabinoid receptor knock-out mice. J. Neurosci. 22 , 9771-9775.

Pertwee, R. G. (2006). Cannabinoid pharmacology: the first 66 years. $B r$. J. Pharmacol. 147, S163-S171.

Pertwee, R. G. (2007). GPR55: a new member of the cannabinoid receptor clan? Br. J. Pharmacol. 152, 984-986.

Pertwee, R. G., Howlett, A. C., Abood, M. E., Alexander, S. P., Di Marzo, V., Elphick, M. R., Greasley, P. J., Hansen, H. S., Kunos, G., Mackie, K., Mechoulam, R., and Ross, R. A. (2010). International Union of Basic and Clinical Pharmacology. LXXIX. Cannabinoid receptors and their ligands: beyond $\mathrm{CB} 1$ and CB2. Pharmacol. Rev. 62, 588-631.

Pistis, M., and Melis, M. (2010). From surface to nuclear receptors: the endocannabinoid family extends its assets. Curr. Med. Chem. 17, 1450-1467.

Rouzer, C. A., and Marnett, L. J. (2011). Endocannabinoid oxygenation by cyclooxygenases, lipoxygenases, and cytochromes P450: cross-talk between the eicosanoid and endocannabinoid signaling pathways. Chem. Rev. 111, 5899-5921.
Ryberg, E., Larsson, N., Sjögren, S., Hjorth, S., Hermansson, N. O., Leonova, J., Elebring, T., Nilsson, K., Drmota, T., and Greasley, P. J. (2007). The orphan receptor GPR55 is a novel cannabinoid receptor. Br. J. Pharmacol. 152, 1092-1101.

Sarnataro, D., Grimaldi, C., Pisanti, S., Gazzerro, P., Laezza, C., Zurzolo, C., and Bifulco, M. (2005). Plasma membrane and lysosomal localization of CB1 cannabinoid receptor are dependent on lipid rafts and regulated by anandamide in human breast cancer cells. FEBS Lett. 579, 6343-6349.

Tsuboi, K., Sun, Y. X., Okamoto, Y., Araki, N., Tonai, T., and Ueda, $\mathrm{N}$. (2005). Molecular characterization of $\mathrm{N}$-acylethanolamine-hydrolyzing acid amidase, a novel member of the choloylglycine hydrolase family with structural and functional similarity to acid ceramidase. J. Biol. Chem. 280, 11082-11092.

Ueda, N., Tsuboi, K., Uyama, T., and Ohnishi, T. (2011). Biosynthesis and degradation of the endocannabinoid 2-arachidonoylglycerol. Biofactors 37, 1-7.

van der Stelt, M., van Kuik, J. A., Bari, M., van Zadelhoff, G., Leeflang, B. R., Veldink, G. A., Finazzi Agro, A., Vliegenthart, J. F., and Maccarrone, M. (2002). Oxygenated metabolites of anandamide and 2-arachidonoyl-glycerol: conformational analysis and interaction with cannabinoid receptors, membrane transporter and fatty acid amide hydrolase. J. Med. Chem. 4, 3709-3720.

van Sickle, M. D., Duncan, M., Kingsley, P. J., Mouihate, A., Urbani, P., Mackie, K., Stella, N., Makriyannis, A., Piomelli, D., Davison, J. S., Marnett, L. J., Di Marzo, V., Pittman, Q. J., Patel, K. D., and Sharkey, K. A. (2005). Identification and functional characterization of brainstem cannabinoid CB2 receptors. Science 310, 329-332.

Viscomi, M. T., Oddi, S., Latini, L., Pasquariello, N., Florenzano, F., Bernardi, G., Molinari, M., and Maccarrone, M. (2009). Selective CB2 receptor agonism protects central neurons from remote axotomy-induced apoptosis through the PI3K/Akt pathway. J. Neurosci. 29, 4564-4570.

Wei, B. Q., Mikkelsen, T. S., McKinney, M. K., Lander, E. S., and Cravatt, B. F. (2006). A second fatty acid amide hydrolase with variable distribution among placental mammals. J. Biol. Chem. 281, 36569-36578. 
Wise, A., and Brown, A. J. (2001). Glaxosmithkline. WO0186305.

Yao, B. B., Mukherjee, S., Fan, Y., Garrison, T. R., Daza, A. V., Grayson, G. K., Hooker, B. A., Dart, M. J., Sullivan, J. P., and Meyer, M. D. (2006). In vitro pharmacological characterization of AM1241: a protean agonist at the cannabinoid CB2 receptor? Br. J. Pharmacol. 149, 145-154.

Zhang, M., Adler, M. W., Abood, M. E., Ganea, D., Jallo, J., and Tuma,
R. F. (2009). CB2 receptor activation attenuates microcirculatory dysfunction during cerebral ischemic/reperfusion injury. Microvasc. Res. 78, 86-94.

Zhang, M., Martin, B. R., Adler, M. W., Razdan, R. K., Jallo, J. I., and Tuma, R. F. (2007). Cannabinoid $\mathrm{CB}(2)$ receptor activation decreases cerebral infarction in a mouse focal ischemia/reperfusion model. J. Cereb. Blood Flow Metab. 27, 1387-1396.
Conflict of Interest Statement: The authors declare that the research was conducted in the absence of any commercial or financial relationships that could be construed as a potential conflict of interest.

Received: 30 November 2011; paper pending published: 16 December 2011; accepted: 27 February 2012; published online: 14 March 2012.

Citation: Battista N, Di Tommaso M, Bari $M$ and Maccarrone $M$ (2012) The endocannabinoid system: an overview. Front. Behav. Neurosci. 6:9. doi: 10.3389/fnbeh.2012.00009

Copyright (c) 2012 Battista, Di Tommaso, Bari and Maccarrone. This is an open-access article distributed under the terms of the Creative Commons Attribution Non Commercial License, which permits non-commercial use, distribution, and reproduction in other forums, provided the original authors and source are credited. 